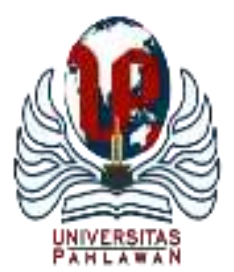

\title{
JURNALBASICEDU
}

Volume 5 Nomor 6 Tahun 2021 Halaman 5336 - 5341

Research \&Learningin Elementary Education https://jbasic.org/index.php/basicedu

\section{Tingkat Resiliensi Orang Tua dalam Mendampingi Anak Sekolah dari Rumah pada Masa Pandemi}

\author{
Nofi Nur Yuhenita ${ }^{1 凶}$ Indiati $^{2}$ \\ Universitas Muhammadiyah Magelang, Indonesia ${ }^{1,2}$ \\ E-mail: nofinury@ummgl.ac.id ${ }^{1}$, indiati.umm@ gmail.com ${ }^{2}$
}

\begin{abstract}
Abstrak
Pandemi Covid-19 sudah ada di sekitar kita hampir 1,5 tahun. Banyak perubahan yang terjadi dalam berbagai aspek, salah satunya adalah aspek pendidikan. Sekolah yang semula dilaksanakan secara tatap muka menjadi dilakukan secara daring. Penelitian ini bertujuan untuk melihat tingkat resiliensi orang tua ketika mendampingi anak menjalani sekolah dari rumah. Penelitian kuantitatif deskriprif menjadi metode untuk mengungkap resiliensi 40 orang tua yang menjadi sampel penelitian. Orang tua yang tidak terbiasa mendampingi anak dalam belajar akan mengalami beban, karena harus terbagi fokus untuk bekerja, menemani belajar dan juga mengurus rumah. Apabila orang tua merasa terbebani maka akan berpengaruh kepada anak, dan meluapkan emosi marah kepada anak. Untuk mengantisipasi rasa terbebani dan menghindari stres dalam mendampimgi anak belajar daring, maka dapat diupayakan untuk menguatkan daya resiliensi orang tua. Skor resiliensi pada sampel penelitian ini berada pada kategori rendah. Hal ini menunjukkan bahwa dalam mendampingi anak sekolah dari rumah mempunyai daya resiliensi yang rendah. Tingkat resiliensi yang rendah akan berdampak pada tingginya tingkat stres.
\end{abstract}

Kata Kunci: Sekolah dari rumah, resiliensi orang tua, masa pandemi

\section{Abstract}

The Covid-19 pandemic has been around us for almost 1.5 years. Many changes have occurred in various aspects, one of which is the education aspect. Schools that were originally held face-to-face are now being conducted online. This study aims to see the level of resilience of parents when accompanying children through school from home. Descriptive quantitative research is a method to reveal the resilience of 40 parents who are the research sample. Parents who are not used to accompanying children in learning will experience a burden, because they have to focus on work, accompanying their studies and also taking care of the house. If parents feel burdened it will affect the child, and vent angry emotions to the child. To anticipate the feeling of being burdened and avoid stress in accompanying children to learn online, efforts can be made to strengthen the resilience of parents. The resilience score in this research sample is in the low category. This shows that in assisting school children from home they have low resilience. A low level of resilience will have an impact on high levels of stress.

Keywords: School from home, Parental Resilience, Pandemic Period

Copyright (c) 2021 Nofi Nur Yuhenita, Indiati

$\triangle$ Corresponding author :

Email : nofinury@ummgl.ac.id

DOI : https://doi.org/10.31004/basicedu.v5i6.1583 
5337 Tingkat Resiliensi Orang Tua dalam Mendampingi Anak Sekolah dari Rumah pada Masa Pandemi Nofi Nur Yuhenita, Indiati

DOI: https://doi.org/10.31004/basicedu.v5i6.1583

\section{PENDAHULUAN}

Pandemi Covid-19 sudah ada di sekitar kita hampir 1,5 tahun. Banyak perubahan yang terjadi dalam berbagai aspek, salah satunya adalah aspek pendidikan dimana dunia pendidikan harus mampu mengikuti kondisi pandemi yang ada(Faiz, Hakam, et al., 2021). Adanya perubahan kebijakan pemerintah Indonesia sebagai upaya memutus mata rantai penyebaran Covid-19(Faiz, 2021). Sekolah yang semula dilaksanakan secara tatap muka menjadi dilakukan secara daring (Wiresti, R. D., \& Munastiwi, 2021). Pemerintah menetapkan kebijakan ini sebagai upaya untuk menekan nyebaran virus Covid-19. Sekolah disinnyalir menjadi salah satu media yang menjadi potensi menyebarkan virus Covid-19, dikarenakan interaksi secara langsung antara siswa, guru, dan orang tua (Chusna, P. A., \& Utami, 2020). Di awal kebijakan penutupan sekolah luring yang hanya dua minggu diperpanjang hingga belum tahu sampai kapan, karena angka penularan yang semakin meningkat. Penerapan belajar dari rumah yang berkepanjangan ini menjadikan guru maupun orang tua mengalami banyak kesulitan dan kendala karena tidak mempunyai persiapan sehingga hal tersebut memunculkan kejenuhan belajar dalam diri siswa (Hanina et al., 2021).

Susilowati, E., \& Azzasyofia, (2020) menyebutkan bahwa data yang diperoleh dari UNESCO, terdapat 68 juta siswa di Indonesia yang menjalani kebijakan belajar dari rumah. Kebiasaan baru ini menjadikan tekanan dan menuntut adanya penyesuaian diri secara tepat dengan pola kebiasaan yang baru. Bagi beberapa orang mungkin akan menjadi hak yang biasa dan dapat dijalani dengan baik-baik saja, akan tetapi pada sebagian yang lain dapat menjadi sumber stress. Hal ini dikarenakan adanya ketidaksiapan baik secara fisik, psikis, maupun aspek lain. Bagi orang tua bekerja maupun non pekerja, kebijakan sekolah dari rumah ini akan menjadikan sebuah persoalan tersendiri (Mansyur, 2020). Mulai dari pengaturan waktu, penguasaan materi, serta menjaga kestabilan emosi anak dan orang tua. Akan tetapi dalam hal ini belum dilihat lebih jauh mengenai bagaimana resiliensi orang tua dalam mendampingi anak belajar di rumah.

Orang tua yang tidak terbiasa mendampingi anak dalam belajar akan mengalami beban, karena harus terbagi fokus untuk bekerja, menemani belajar dan juga mengurus rumah (Sari, 2021). Apabila orang tua merasa terbebani maka akan berpengaruh kepada anak, dan meluapkan emosi marah kepada anak. Berdasarkan data dari Sistem Informasi Online Perlindungan Perempuan dan Anak atau disingkat SIMFONI PPA. Sejaktanggal 1 Januari 2020 sampai 23 September 2020 menunjukkan bahwa kekerasan terhadap anak di Indonesia sebanyak 5.697 kasus dengan 6.315 korban (Faiz, Soleh, et al., 2021). Untuk mengantisipasi rasa terbebani dan untukmenghindari stres dalam mendampingi anak belajar daring, maka dapat diupayakan untuk menguatkan daya resiliensi orang tua (Priyanto, A., \& Ag, 2020).

Penelitian ini akan melihat tingkat resiliensi yang dialami oleh orang tua dalam mendampingi anak belajar dari rumah. Resiliensi merupakan kemampuan dalam mempertahankan diri dari stres. Resiliensi merupakan bagian dari psikologi positif, resiliensi akan mengarahkan individu untuk memaknai kembali kualitas hidup dan mengarahkannya pada gaya hidup yang positif (Akbar, Z., \& Pratasiwi, 2017). Hasil akhir yang diharapkan dari resiliensi adalah untuk membentuk individu untuk memaknai kembali kualitas hidup dan mengarahkannya pada gaya hidup yang positif dan mampu menghadapi stres dan trauma yang menimpa (Katodhia, L., \& Sinambela, 2020). Connor, K. M., Davidson (2003) mendefinisikan resiliensi sebagai kualitas individu dalam menghadapi, mengatasi, mempelajari, dan berubah melalui kesulitan hidup yang tak terhindarkan. Resiliensi dapat digunakan oleh orang tua sebagai sumber kekuatan dalam menghadapi kesulitan.

Penelitian ini akan menganalisa bagaimana resiliensi orang tua dalam mendampingi anak belajar dari rumah. Hasil penelitian ini akan menjadi dasar untuk menentukan treatmen dan layanan bimbingan konseling dalam mengembangkan dan meningkatkan daya resiliensi. Hasil penelitian ini juga dapat dijadikan panduan untuk mengembangkan metode layanan sehingga diperoleh metode yang tepat dan solutif dalam 
5338 Tingkat Resiliensi Orang Tua dalam Mendampingi Anak Sekolah dari Rumah pada Masa PandemiNofi Nur Yuhenita, Indiati

DOI: https://doi.org/10.31004/basicedu.v5i6.1583

menyelesaikan permasalahan dalam pendampingan sekolah dari rumah. Apabila orang tua tenang dan dapat mengatur emosi maka anak akan dapat belajar dengan rasa aman dan nyaman.

\section{METODE}

Dalam penelitian ini menggunakan metode penelitian kuantitatif deskriprif untuk mengungkap resiliensi 40 orang tua yang menjadi sampel penelitian. Sampel dalam penelitian ini adalah sejumlah 40 orang tua di wilayah Magelang yang mendampingi anak sekolah dari rumah. Instrumen untuk mengumpulkan data yang digunakan adalah skala resiliensi, wawancara dan observasi kepada orang tua. Waktu pengumpulan data dari tanggal 1 sampai 10 Juni 2021.Analisa data dilakukan untuk mengatahui tingkat resiliensi orang tua.

\section{HASIL DAN PEMBAHASAN}

Pendidikan memiliki peranan yang sangat penting untuk memajukan sebuah negara, pendidikan mempunyai peran yang amat strategis dalam menyiapkan sebuah generasi muda yang memiliki sebuah pengetahuan serta memiliki kecerdasan yang sangat tinggi dan bisa mengguasai softskil yang luas (Irlana et al., 2021). Di tengah kondisi saat ini proses pendidikan menjadi berubah dan berpusat kepada peran orang tua untuk mampu bertahan dalam kondisi pandemi yang berkepanjangan.

Berdasarkan pada hasil penelitian yang dilakukan pada sejumlah 40 responden orang tua yang mendampingi anak sekolah dari rumah, diperoleh data skor resiliensi seperti pada tabel.

Tabel Skor Resiliensi

\begin{tabular}{llllllll}
\hline Subjek & SkorResiliensi & Subjek & SkorResiliensi & Subjek & SkorResiliensi & Subjek & SkorResiliensi \\
\hline 1 & 35.00 & 11 & 40.00 & 21 & 47.00 & 31 & 41.00 \\
2 & 39.00 & 12 & 41.00 & 22 & 45.00 & 32 & 41.00 \\
3 & 48.00 & 13 & 49.00 & 23 & 41.00 & 33 & 45.00 \\
4 & 42.00 & 14 & 43.00 & 24 & 47.00 & 34 & 51.00 \\
5 & 43.00 & 15 & 44.00 & 25 & 43.00 & 35 & 44.00 \\
6 & 41.00 & 16 & 50.00 & 26 & 43.00 & 36 & 41.00 \\
7 & 37.00 & 17 & 39.00 & 27 & 34.00 & 37 & 42.00 \\
8 & 39.00 & 18 & 35.00 & 28 & 51.00 & 38 & 40.00 \\
9 & 42.00 & 19 & 48.00 & 29 & 42.00 & 39 & 41.00 \\
10 & 37.00 & 20 & 40.00 & 30 & 40.00 & 40 & 30.00 \\
\hline
\end{tabular}

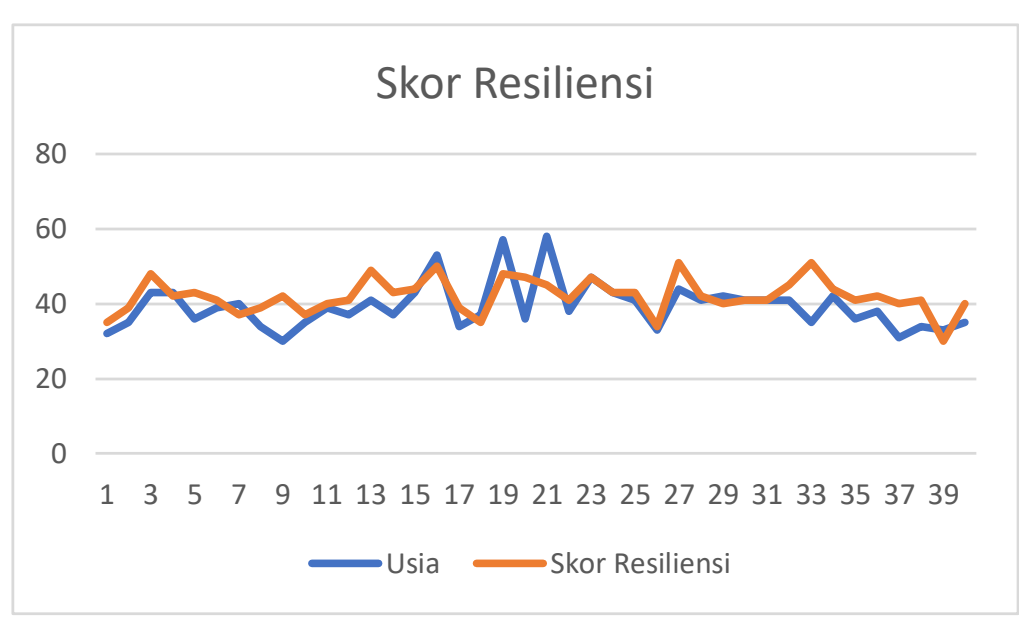

Gambar Grafik Usia dan Skor Resiliensi 
5339 Tingkat Resiliensi Orang Tua dalam Mendampingi Anak Sekolah dari Rumah pada Masa PandemiNofi Nur Yuhenita, Indiati

DOI: https://doi.org/10.31004/basicedu.v5i6.1583

Berdasarkan skor resiliensi pada sampel penelitian ini berada pada kategori rendah. Hal ini menunjukkan bahwa dalam mendampingi anak sekolah dari rumah mempunyai daya resiliensi yang rendah. Tingkat resiliensi yang rendah akan berdampak pada tingginya tingkat stres. Hal ini menunjukkan bahwa pentingnya pendampingan anak ketika pembelajaran dari rumah untuk mengedukasi orang tua yang memiliki tingkat resiliensi rendah. Salah satu upaya yang bisa dilakukan guru adalah dengan home visit, agar siswa dapat didampingi oleh guru meskipun tidak banyak waktunya. Para orang tua menyampaikan bahwa proses pembelajaran akan lebih efektif jika dilakukan secara tatap muka. Akan tetapi orang tua juga merasa khawatir jika anak-anak terpapar Covid-19. Para orang tua menyampaikan jika pembelajaran daring tanpa diberikan materi akan menjadikan anak bertanya pada orang tua.

Kondisi pandemiyang mengharuskan proses pembelajaran dilaksanakan dengan metode daring menjadi salah satu pemicu stress pada banyak orang, termasuk orang tua. Pembelajaran dari rumah atau daring jugamembuat siswa dan orang tua tertekan. Hal ini tidak hanya meningkatkan tingkat stres namun juga bisa meningkatkan resiko kekerasan antara orang tua dan anaknya/ siswa (Faiz, Soleh, et al., 2021). Pada sisi lain, orang tua mempunyai tanggung jawab dan peran yang cukup banyak. Peran dalam pembelajaran yang sebelum pandemi dilakukan oleh guru, saat ini porsi peran orang tua menjadi lebih besar dalam mendampingi anak belajar di rumah. Sekolah yang dilaksanakan dari rumah juga mempunyai berbagai kendala sehingga banyak orang tua yang meminta sekolah untuk melaksanakan pembelajaran tatap muka. Hal ini dikarenakan banyak orang tua yang kurang memahami materi belajar, kesulitan dalam menumbuhkan minat belajar, waktu yang kurang karena harus bekerja, bahkan kesulitan dalam mengoperasikan gadget dan sulitnya jaringan internet. Berbagai kendala ini disinyalir dapat memicu munculnya stres pada orang tua.

Salah satu konsep yang sangat berpengaruh pada penanganan stres adalah resiliensi. Resiliensi merupakan kemampuan untuk mencapai, bangkit kembali, atau mendapatkan kembali kesehatan fisik dan emosional seperti sebelum terjadinya suatu tragedi, kesulitan, peristiwa yang tidak diinginkan, atau suatu stressor yang signifikan (Stuart, 2013). Seseorang dengan resiliensi yang baik, seharusnya akan berhasil melewati masalah yang sedang dihadapinya, walaupun secara perlahan. Resiliensi merupakan suatu usaha dari individu sehingga mampu beradaptasi dengan baik terhadap keadaan yang menekan, sehingga mampu untuk pulih dan berfungsi optimal dan mampu melalui kesulitan(Missasi \& Izzati, 2019).

Secara umum resiliensi merujuk pada faktor-faktor yang membatasi perilaku negatif yang dihubungkan dengan stres dan hasil yang adaptif meskipun dihadapkan dengan kemalangan atau kesengsaraan (Waxman, H. C., Gray, J. P., \& Padron, 2003). Resiliensi dapat berperan sebagai penghambat terhadap perkembangan dari kenaikan tingkat ansietas dan depresi seorang individu, yang berhubungan dengan tingkat stres orang tua yang tinggi (Bitsika, V., Sharpley, C. F., \& Bell, 2013). Sebagai tambahan, penelitian lain juga menyebutkan bahwa resiliensi keluarga yang tinggi memiliki asosiasi dengan tingkat stres keluarga yang rendah (Plumb, 2011).

Sekolah dari rumah tentu berbeda dengan sekolah tatap muka di sekolah. Banyak orang tua yang tidak siap merangkap tanggung jawab mengerjakan pekerjaan rumah sekaligus menjadi guru pengganti. Hal ini dapat lebih memicu stressor ditambah dengan kekhawatiran orang tua terhadap virus Covid-19. Kondisi ini bagi kebanyakan orang tua menjadikan terpancing emosi. PKPPA mendata bahwa selama Covid 19, dalam bulan April 2020 terdapat peningkatan kasus kekerasan pada anak yaitu terdapat 368 kasus yang dialami oleh 407 anak (Rezkisari, 2020).

\section{KESIMPULAN}

Kondisi pembelajaran yang mengharuskan peran orang tua mengganti peran guru membuat siswa dan orang tua rentan terhadap kondisi stres bahkan kekerasan fisik sehingga membutuhkan tingkat resiliensi yang baik agar dapat mengurangi tingkat stres dalam lingkungan keluarga. Perlunya edukasi dari berbagai pihak 
5340 Tingkat Resiliensi Orang Tua dalam Mendampingi Anak Sekolah dari Rumah pada Masa Pandemi Nofi Nur Yuhenita, Indiati

DOI: https://doi.org/10.31004/basicedu.v5i6.1583

diharap mampu memberikan pemahaman bagi orang tua dan siswa. Selain itu, peran guru kunjung diperlukan dalam proses pendampingan antara guru, orang tua dan siswa untuk terus menjalankan roda pendidikan sebaik mungkin.

\section{DAFTAR PUSTAKA}

Akbar, Z., \& Pratasiwi, R. (2017). Resiliensi Diri Dan Stres Kerja Pada Guru Sekolah Dasar. Jppp-Jurnal Penelitian Dan Pengukuran Psikologi, 6(2), 106-112.

Bitsika, V., Sharpley, C. F., \& Bell, R. (2013). The Buffering Effect Of Resilience Upon Stress, Anxiety And Depression In Parents Of A Child With An Autism Spectrum Disorder. Journal Of Developmental And Physical Disabilities, 25(5).

Chusna, P. A., \& Utami, A. D. M. (2020). Dampak Pandemi Covid-19 Terhadap Peran Orang Tua Dan Guru Dalam Meningkatkan Kualitas Pembelajaran Daring Anak Usia Sekolah Dasar. Premiere: Journal Of Islamic Elementary Education, 2(1), 11-30.

Connor, K. M., Davidson, J. R. (2003). Development Of A New Resilience Scale: The Connor-Davidson Resilience Scale (Cd-Risc). Depression And Anxiety, 18, 17-82.

Faiz, A. (2021). Peran Filsafat Progresivisme Dalam Mengembangkan Kemampuan Calon Pendidik Di Abad21. Jurnal Education And Development Institut Pendidikan Tapanuli Selatan, 9(1), 131-135.

Faiz, A., Hakam, K. A., Nurihsan, J., \& Komalasari, K. (2021). Development Of Moral Dilemma Model In Elementary School. 1st International Conference In Education, Science And Technology, 17-22.

Faiz, A., Soleh, B., Kurniawaty, I., \& Purwati. (2021). Tinjauan Analisis Kritis Terhadap Faktor Penghambat Pendidikan Karakter Di Indonesia. Jurnal Basicedu, Volume 5(4), 1766-1777. Https://Doi.Org/Https://Doi.Org/10.31004/Basicedu.V5i4.1014

Hanina, P., Faiz, A., \& Yuningsih, D. (2021). Upaya Guru Dalam Mengatasi Kejenuhan Belajar Peserta Didik Di Masa Pandemi. Basicedu, 5(5), 3791-3798. Https://Doi.Org/10.31004/Basicedu.V5i5.1402

Irlana, A., Retnasih, E., \& Faiz, A. (2021). Kolaborasi Manajemen Sekolah Dalam Meningkatkan Kualitas Pembelajaran Di Uptd Sdn 6 Margadadi. 246-253.

Katodhia, L., \& Sinambela, F. C. (2020). Efektivitas Pelatihan Emotional Intelligence Untuk Meningkatkan Resiliensi Pada Siswi Smp Yang Melakukan Self Injury. Journal An-Nafs: Kajian Penelitian Psikologi, 5(2), 114-131.

Mansyur, A. R. (2020). Dampak Covid-19 Terhadap Dinamika Pembelajaran Di Indonesia. Education And Learning Journal, 1(2), 113-123.

Missasi, V., \& Izzati, I. D. C. (2019). Faktor-Faktor Yang Mempengaruhi Resiliensi. Prosiding Seminar Nasional Magister Psikologi Universitas Ahmad Dahlan, 433-441.

Plumb, J. C. (2011). The Impact Of Social Support And Family Resilience On Parental Stress In Families With A Child Diagnosed With An Autism Spectrum Disorders. University Of Pennsylvania.

Priyanto, A., \& Ag, M. (2020). Pembelajaran Daring. Penerapan Adaptasi Kebiasaan Baru Pada Era Pandemi Virus Corona 19 Di Berbagai Sektor Pendidikan.

Rezkisari, I. (2020). Covid-19 Dan Kekerasan Anak Yang Meningkat.

Sari, N. (2021). Peran Orang Tua Dalam Mendampingi Anak Belajar Online Dan Hasil Belajar Siswa Kelas Iii Mi Al-Islam Kota Bengkulu. Uin Fatmawati Sukarno.

Stuart, G. W. (2013). Buku Saku Keperawatan Jiwa. Egc.

Susilowati, E., \& Azzasyofia, M. (2020). The Parents Stress Level In Facing Children Study From Home In The Early Of Covid-19 Pandemic In Indonesia. International Journal Of Science And Society, 2(3), 1- 
5341 Tingkat Resiliensi Orang Tua dalam Mendampingi Anak Sekolah dari Rumah pada Masa Pandemi Nofi Nur Yuhenita, Indiati

DOI: https://doi.org/10.31004/basicedu.v5i6.1583

12.

Waxman, H. C., Gray, J. P., \& Padron, Y. N. (2003). Review Of Research On Educational Resilience. Center For Research On Education, 11.

Wiresti, R. D., \& Munastiwi, E. (2021). Deskripsi Rekonstruksi Pembelajaran Anak Usia Dini Study From Home Pada Masa Pandemik Covid-19. Jurnal Ilmiah Visi, 16(1), 47-56. 